\title{
De invloed van Europeanisering op de constitutionele verhoudingen in Nederland
}

\author{
Leonard F.M. Besselink
}

\begin{abstract}
Samenvatting
In dit artikel wordt bekeken welke invloed het proces van Europese integratie heeft gehad op constitutionele verhoudingen in Nederland. In deze verhoudingen is de rol van de uitvoerende en rechterlijke macht versterkt ten koste van die van het parlement. Hoewel dit deels ook het gevolg is van binnenlandse ontwikkelingen, zijn deze verschuivingen mede veroorzaakt door de EU. Opvallend is ook het ontbreken van een debat over de rol van de EU en het Europees recht in de Nederlandse constitutionele orde en het ontbreken van aanpassingen aan de grondwet zelf. Dit kan enerzijds verklaard worden uit de openheid voor de internationale rechtsorde die de Nederlandse constitutie kenmerkt en anderzijds uit het feit dat veel constitutionele praktijken niet formeel in de grondwet zijn vastgelegd.
\end{abstract}

\section{Summary}

This article examines the impact of European integration on the Dutch constitutional order. It argues that within this constitutional order, the roles of the executive and the judiciary have been strengthened at the expense of the role of parliament. Although these shifts are partly the outcome of domestic developments, they have also been caused by the process of European integration. Within the Netherlands, there has hardly been any debate on the role of the EU and EU law in the Dutch constitutional order and no formal changes to the written constitution have been made. This can be explained, on the one hand, from the openness of the Dutch legal order for international law and, on the other hand, from the fact that many constitutional practices have not been codified in the formal constitution.

\section{$1 \quad$ Inleidende opmerkingen}

In dit opstel wordt beschreven in hoeverre de Nederlandse constitutie en constitutionele verhoudingen veranderd zijn onder invloed van de Europese integratie in het kader van de Europese Unie. Hoe resistent is de constitutie tegen EU invloed? Op welke punten is zij niet resistent gebleken?

Als eerste moet verhelderd worden wat bedoeld kan worden met 'constitutie' als we spreken over de invloed daarop vanuit de EU. We moeten daarbij tussen twee dingen onderscheiden. Ten eerste is er het formele tekstuele kader van constitutionele documenten waarin normen, regels en beginselen zijn vastgelegd die instellingen constitueren en bevoegdheden attribueren en reguleren (formele constitutie). Ten tweede maakt het geheel aan daadwerkelijke patronen in het functioneren van de staatsinstellingen en de constitutionele praktijk deel uit van de constitutie (materiële 
constitutie). In dit verband moeten we oog houden voor de typische kenmerken van de Nederlandse constitutie voor wat betreft de verhouding tussen de aldus geduide formele en materiële constitutie.

Wat dit laatste betreft valt grosso modo te onderscheiden tussen twee typen van constituties: constituties waarin het formele element overweegt en constituties die veel sterker openstaan voor materiële ontwikkelingen. Men kan aldus onderscheiden tussen twee categoriën of typen van constituties.

Enerzijds bestaan er constituties die revolutionair zijn, veelal hun oorsprong hebben in een politieke ramp, zoals oorlog of een omwenteling. Deze constituties beschouwen de geschiedenis als een "nie wieder". De grondwet is een blauwdruk die schoon schip maakt met het verleden.

Daartegenover bestaan er ook constituties die vooral een weerslag willen zijn van historische ontwikkelingen, die zich incrementeel ontwikkelen, uitgaan van historische continuïteit, die eerder willen codificeren dan modificeren. Zij absorberen in die continuïteit de verschillende grotere en kleinere lotgevallen, waaruit hervormingen voortvloeien die echter worden beschouwd als één grote constitutionele ontwikkeling, niet als telkens nieuwe constituties.

In het eerste type constitutie overweegt het formele element en zijn juridische afdwinging en uitleg overheersend; in het tweede type constitutie overwegen materiële praktijken, staat men open voor allerlei praktische ontwikkelingen, gewoontes en praktijken, en is juridische handhaving secundair.

Het oertype van de eerste waren (sommige van) de Europese grondwetten die hun oorsprong vonden in de Franse revolutie; het model van het tweede type is de Britse constitutie. In recente tijden moeten grondwetten als de Duitse en Italiaanse tot het eerste type worden gerekend; tot het tweede behoren behalve de Britse in wezen ook de scandinavische grondwetten, zelfs na de grondwetsherzieningen die de scandinavische landen in de afgelopen decennia hebben doorgevoerd.

Ik sta op het standpunt dat de Nederlands constitutie tot het laatste type behoort. Het gaat om een flexibele constitutie, waarbij in de formele constitutie - de Grondwet - over het algemeen pas iets wordt opgenomen als dat al vaststaande en algemeen geaccepteerde praktijk is geworden. Het veranderen van politieke praktijken door grondwetswijziging is uiterst zeldzaam. Voorzover het de rol van de volksvertegenwoordiging en het regeerstelsel betreft is een dergelijke wijziging sinds de grondwetsherziening van 1917 niet meer voorgekomen. ${ }^{1}$

Niettegenstaande de aanwezigheid van een geschreven grondwet, wordt dit document in de politieke praktijk niet erg serieus genomen. Van de twee constitutionele regels die enige rol spelen in de politieke praktijk, is er één niet in de Grondwet vastgelegd, nl. de gewoonterechtelijke regel dat een kabinet het ontslag moet indienen als blijkt van wantrouwen in de Tweede Kamer. De andere regel, dat de regering de kamers en kamerleden de inlichtingen verstrekt waarom zij vragen, is wel vastgelegd in de

\footnotetext{
${ }^{1}$ Potentieel hadden de grondwetswijzigingen van bepalingen over de buitenlandse betrekkingen, m.n. de parlementaire bevoegdheden tav verdragsgoedkeuring en de bepaling over de in-oorlog-verklaring een nieuwe praktijk kunnen inleiden, zoals de bedoeling was met de herziening van 1922. Ten aanzien van de verdragsgoedkeuring is dat echter hooguit gedeeltelijk gelukt. Pas de grondwetswijzigingen van de jaren ' 50 maakten een echte wijziging mogelijk, maar in verband met de ontsnappingsclausules is die in de praktijk nog niet eens geheel geslaagd; ten aanzien van de in-oorlog-verklaring heeft men in de praktijk van deze bepaling een dode letter gemaakt.
} 
Grondwet (artikel 68). Daarbuiten wordt zelden of nooit enig constitutioneel argument gebezigd dat een wezenlijke rol speelt in de beraadslaging en besluitvorming. Het is not done om een politiek debat te willen winnen met wat gezien wordt als 'juridische' argumenten. Slechts de Eerste Kamer wil een enkele keer nog wel een kwestie van constitutionele aard aan de orde stellen. De Tweede Kamer laat zich hier vervolgens meestal niets aan gelegen liggen, zodat een eventuele standpuntbepaling van de Eerste Kamer niet beklijft.

Een zekere uitzondering op de boterzachtheid van de Grondwet is gelegen in de toetsing door de rechter aan grondrechten. Deze toetsing beperkt zich echter vooral tot toetsing van gemeentelijke verordeningen aan de grondwettelijke grondrechten, omdat de wet vooralsnog niet aan Grondwet getoetst kan worden (artikel 120 Grondwet). Overigens is er een wijziging van dit toetsingsverbod aanhangig, die beoogt toetsing van de wet aan de grondwetsbepalingen over de klassieke vrijheidsrechten mogelijk te maken. Toetsing van de de wet aan de overige bepalingen van de Grondwet is echter uitgesloten, zodat de wet niet toetsbaar is aan bijvoorbeeld de sociale grondrechten, aan de decentralisatiebepalingen en aan onder meer procedurebepalingen waaraan de wetgever gebonden is. Dit laatste is het bereik van 'politieke besluitvorming' en daar dient de rechter buiten te blijven, zo is de opvatting.

Hierdoor is toetsing van de wet en de wetgevingsprocedure aan de Grondwet voorbehouden aan de wetgever zelf. Terwijl de buitenstaander dan zou denken dat daarom de Staten-Generaal in elk der kamers een goede procedure zouden hebben waarbij wetsontwerpen diepgaand worden onderzocht op hun grondwettigheid en getoetst worden aan grondwetsbepalingen, zoals bijvoorbeeld het geval is in Finland en het VK (wat het laatste land betreft: toetsing aan de grondrechten van het EVRM), komt bedrogen uit. De kamers hebben geen enkele procedure waarin specifiek wordt nagegaan of wetsontwerpen met de Grondwet in overeenstemming zijn. Het is dan ook uiterst zeldzaam dat bij de behandeling van beleidsonderwerpen of wetsvoorstellen enig constitutioneel debat van betekenis wordt gevoerd.

Ook overigens is in Nederland het constitutioneel debat zo goed als afwezig. Dit geldt ook de constitutionele ontwikkelingen rond de Europese Unie, zowel voor wat betreft de Unie zelf, als voor wat betreft de gevolgen van de EU voor het nationale constitutionele bestel.

Als wij nagaan wat de invloed van de Europeanisering is op de constitutionele verhoudingen, dan moeten we dus bedenken dat de rol van de formele constitutie, de Grondwet, niet erg maatgevend is; we moeten ook kijken naar de constitutionele praktijken en de patronen die daarin gevolgd worden en hoe deze wel of niet op gespannen voet raken met de formele constitutie.

Dergelijke praktijken en patronen worden in hoge mate gevoed door ontwikkelingen op de twee andere niveau's: die van beleidsvorming en beleidsuitvoering. Er is dus in een constitutionele situatie als zich in Nederland voordoet, sprake van een voortdurende interactie tussen verschillende niveaus die elkaar wederzijds beïnvloeden.

We bespreken thans een aantal van de verschuivingen die zich in de constitutionele verhoudingen hebben voorgedaan. Eerst zullen we ingaan op de omkering van de trias; daarna zullen we kort iets zeggen over het afwezig zijn van een discussie over de voorrang van EG-recht op nationaal recht; om ten slotte enige woorden te wijden aan de 
vraag in hoeverre de ontwikkelingen die we aanstipten werkelijk veroorzaakt worden door de Europese integratie.

\section{De omkering van de trias}

Wanneer we ons de verhoudingen tussen de drie staatsmachten in de klassieke opvatting van de trias politica als een driehoek voorstellen, dan staat klassiek de wetgever aan de top van de driehoek, terwijl aan elke punt van de basis de uitvoerende en rechtsprekende macht te plaatsen zijn. Dat is althans de klassieke, normatieve visie op de verhouding tussen de drie machten van de trias politica. De wetgever, dat is de volksvertegenwoordiging, maakt de wetten die de bevolking kunnen binden, plichten opleggen en rechten scheppen en wijzigen. De executieve, dat is de regering, heeft de wetten tot uitvoering te brengen, en is daarom ondergeschikt aan de wetgevende macht. De rechter, die heeft te oordelen over de uitleg en toepassing van de wet, is daarbij primair aan de wet gebonden, en in die zin aan de wetgever onderworpen.

wetgever

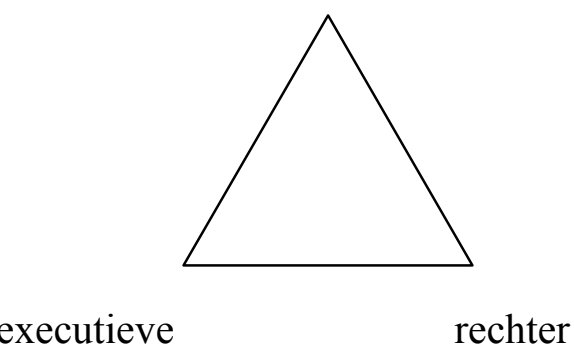

Eén van de meest opvallende verschijnselen van de $20^{\mathrm{e}}$ eeuw, is dat in werkelijkheid de driehoek omgekeerd lijkt te zijn geworden.

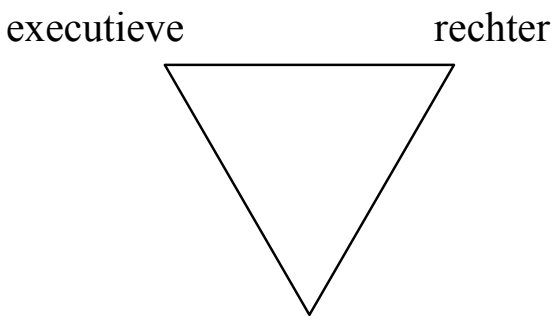

wetgever

\section{$2.1 \quad$ De executieve}

De cruciale rol van de executieve kwam al tot uiting kwam in haar dominantie van het wetgevend proces, doordat zij in de praktijk, ondersteund door een ambtenarenapparaat dat geen tegenhanger vindt in de ondersteuning van de volksvertegenwoordiging, nagenoeg altijd het initiatief neemt en vervolgens ook het uitvoeringstraject beheerst. De Europese integratie in het kader van de Europese Gemeenschap en Europese Unie heeft dit aanzienlijk versterkt. 
De vertegenwoordiging van de lidstaten wordt vooral geconcentreerd in de Raad, waar althans wat Nederland betreft ${ }^{2}$ - uitsluitend regeringsvertegenwoordigers deel van uitmaken. Hoewel het EG-verdrag stelt dat het Europees Parlement bestaat uit vertegenwoordigers van de volkeren van de lidstaten, ${ }^{3}$ en ook als we moeten vaststellen dat het Europees Parlement is geëvolueerd tot medewetgever in de meeste gevallen waarin EG-regelgeving tot stand moet worden gebracht, toch vormt dit geen tegenwicht in representatief opzicht tegen de executieve dominantie van de Raad. Dit wordt eensdeels veroorzaakt doordat de representativiteit van de leden van het Europees Parlement vanwege de immer zeer lage opkomst bij verkiezingen voor het EP ongunstig afsteekt tegen die van het nationale parlement.

Bovendien is het in de praktijk zo, dat Nederlandse Europarlementariërs in de praktijk geen lid zijn van de Staten-Generaal - er is zelfs wel voorgesteld om een eventueel 'dubbelmandaat' te verbieden. ${ }^{4}$ Daardoor is de band tussen de nationale volksvertegenwoordiging en de Europese volksvertegenwoordiging verbroken. Het nationale parlement is daardoor in institutioneel opzicht afgesneden geraakt van de Europese besluitvorming - zodat men alleen nog overhoudt de meer indirecte vormen van parlementaire beïnvloeding door nationale scrutiny van de Europese besluitvorming.

\subsubsection{De verticale wetgevingsketen}

De verticale machtenverdeling in de EU is een ander element dat de executieve dominantie in de hand werkt: de besluiten die men op het niveau van de EU neemt, dienen voor het overgrote deel van de gevallen worden uitgevoerd op nationaal niveau. Waar het gaat om implementatie door nationale regelgeving, heeft het nationale parlement vaak het nakijken. Zeer vaak wordt er in de nationale wetgeving voor gekozen om EG-implementatie te laten geschieden door lagere regelgeving, dat wil zeggen door regeringsbesluiten (algemene maatregelen van bestuur) of ministeriële besluiten, juist ook wanneer normaliter de betreffende regelgeving bij wet zou geschieden.

De meest extreme vorm is de zgn. 'versnelde' implementatie door lagere regelgeving waarbij de lagere regeling de formele wet kan wijzigen; hierdoor wordt het parlement dus definitief uitgeschakeld, zij het omdat de formele wet (en dus het parlement zelf) daarmee akkoord gegaan is.

Hoewel er al enkele voorbeelden bestonden van dergelijke 'Hendrik VIII-clausules', heeft de Eerste Kamer in 1998, toen zo'n clausule werd voorgesteld in de Telecommunicatiewet, daar fundamentele bezwaren tegen geopperd. Ten principale werd gesteld dat dergelijke clausules in strijd zijn, althans op gespannen voet staan, met de

\footnotetext{
${ }^{2}$ De Duitse vertegenwoordiging bestaat soms, afhankelijk van de aard van de materie die in de Raad geagendeerd is, uit leden van de Bundesrat.

${ }^{3}$ Artikel 189 EG: 'Het Europees Parlement, bestaande uit vertegenwoordigers van de volkeren van de staten die in de Gemeenschap zijn verenigd, oefent de door dit Verdrag aan deze instelling verleende bevoegdheden uit.'

${ }^{4}$ Dit zou overigens in strijd zijn met het nog steeds geldende artikel 5 van de Akte voor de Verkiezing van de vertegenwoordigers in het Europees Parlement door middel van rechtstreekse algemene verkiezingen: 'De hoedanigheid van vertegenwoordiger in het Europees Parlement is verenigbaar met die van lid van het parlement van een lidstaat.'

${ }^{5}$ Tijdens zijn regering vaardigde Hendrik VIII vele Royal Proclamations uit, die in zijn bedoeling wetgeving behelsden. Zij verkregen ook daadwerkelijk kracht van wet door een Act of Parliament van 1539, waardoor de facto en de iure wetten konden worden gemaakt, gewijzigd en ingetrokken bij Royal Proclamation.
} 
Grondwet, in het bijzonder de attributie in artikel 81 van de Grondwet van wetgevende bevoegdheid aan de formele wetgever (Staten-Generaal en regering tezamen). Deze attributie van wetgevende macht mag daarom niet door de wetgever ongedaan worden gemaakt door een blanco-delegatie aan de regering (of zelfs individuele ministers) van de bevoegdheid om wetten te wijzigen, zo werd geredeneerd. Deze discussie leidde tot een omvangrijk dossier, met daarin een nota van een interdepartementale commissie, ${ }^{6}$ een kritisch advies van de Raad van State hierover, ${ }^{7}$ een daarop aangepast kabinetsstandpunt van het kabinet-Kok ${ }^{8}$ waarin deze vorm van implementatie slechts onder bepaalde omstandigheden toelaatbaar wordt geacht, vele schriftelijke stukkenwisselingen en enkele debatten in de Eerste Kamer (de Tweede Kamer liet nagenoeg geheel verstek gaan ${ }^{9}$ ), een motie die de noodzaak van het scheppen van een grondwettelijke basis aangeeft, en een omvangrijke studie naar de problematiek in opdracht van de minister van Binnenlandse zaken en koninkrijksrelaties (Besselink c.s. 2002). Dit alles leidde ertoe dat het kabinet afzag van het inwerking laten treden van de betreffende bepaling in de Telecommunicatiewet.

Desalniettemin gaat het huidige kabinet unverfroren verder met het invoeren van zeer ruime delegatie-clausules, zelfs met nagenoeg identieke bepalingen als in de Telecommunicatiewet ontoelaatbaar werden geacht. Komt de regering de Eerste Kamer, of recentelijk zelfs de Tweede Kamer op haar pad tegen, dan wordt er met een omtrekkende beweging duidelijk gemaakt dat het om tijdsredenen echt nodig is een dergelijke constructie te kiezen. Het lijkt erop dat er op dit moment een kleine slag plaatsvindt tussen de regering en enkele kamerleden die het gevoel hebben gepasseerd te raken door de manoeuvre van delegatie zodra het gaat om uitvoering van EG-besluiten. Naar het kabinetsstandpunt van het kabinet-Kok verwijst het huidige kabinet niet meer en al evenzeer mijdt het elke verwijzing naar constitutionele complicaties.

De minister van Justitie heeft in juli 2004 een kader voor implementatie ontwikkeld waarin duidelijk wordt gemaakt dat het een uitgangspunt is dat de wetgever, en dus de Staten-Generaal, niet langer, althans zo min mogelijk, bij implementatie-regelgeving betrokken dient te zijn. Zelfs wanneer een EG-richtlijn beleidsruimte laat aan de nationale regelgever, is in dat geval niet de Staten-Generaal, maar de regering de aangewezene om te implementeren, zo stelt de minister; wanneer er weinig beleidsruimte is dan dient de wetgever te delegeren aan de minister die de regels maakt die hij zelf heeft uit te voeren (hoezo scheiding van machten?); de wetgever, dat wil zeggen het parlement, zal er alleen bij ingrijpende keuzes (whatever that may be) aan te pas komen. ${ }^{10}$ In de fase

\footnotetext{
${ }^{6}$ Versnelde implementatie van EG- en andere internationale besluiten, Advies van de Interdepartementale Commissie Europees Recht, februari 1999, 24 pp.

${ }^{7}$ Kamerstuk 26200 VI, B.

${ }^{8}$ Kamerstukken 26200 VI, nr. 65, 7 pp.

${ }^{9}$ In de Tweede Kamer heeft slechts een oppervlakkig commissie-overleg gehad over het kabinetsstandpunt. In de Eerste Kamer heeft men tijdens het debat over het kabinetsstandpunt de 'afgrijselijke' kwaliteit van het debat over hetzelfde onderwerp in de Tweede Kamer geweten aan het gegeven dat men in de Tweede Kamer de stukken van de Eerste Kamer niet leest, zie Handelingen EK 10 oktober 2000, p. 2-57.

${ }^{10}$ Kamerstukken Eerste Kamer, 29200 VI, F 2e Herdruk, Brief van de Minister van Justitie aan de Eerste Kamer, 27 juli 2004, p. 2: 'Voor zover de betrokken richtlijn de lidstaten bij de implementatie niet of nauwelijks beleidsruimte laat, wordt bij voorkeur gedelegeerd aan de betrokken minister; in andere gevallen in beginsel aan de regering. Zo kan worden bereikt dat de situatie waarin een richtlijn noodzaakt tot formele wetgeving in beginsel beperkt blijft tot situaties waarin de Grondwet formele wetgeving eist of
} 
van voorbereiding van de richtlijn zou meer intensieve betrokkenheid van het parlement wél mogelijk moeten zijn omdat dan er nog wel enige keuzeruimte zou bestaan. ${ }^{11}$ In noodgevallen zou men 'naar bevind van zaken' moeten handelen - waarmee kennelijk bedoeld wordt dat de regering zich dan niet aan de uiteengezette lijn gebonden acht, hetgeen niets anders kan betekenen dan dat in zulke gevallen het parlement geheel buiten spel kan worden gezet. In een veelzeggende slotpassage wijst de minister erop dat met zijn stellingname de discussie over wetgevingstechniek kan worden afgesloten, terwijl in een later stadium 'een meer fundamentele gedachtewisseling over de rol van de EU in de Grondwet en de wenselijkheid van bijzondere procedures voor (tijdige totstandkoming van) implementatiewetgeving' kan worden gehouden naar aanleiding van de EK motie van december 2000 waarmee het allemaal begonnen is: dat de Grondwet met het reeds gestelde in het geding zou zijn, wordt daarmee impliciet ontkent. ${ }^{12}$ Met andere woorden, dat niet de wetgever maar de regering of individuele ministers het primaat in de regelgeving in EU context heeft, wordt niet gezien als iets dat de Grondwet raakt, maar is alleen een kwestie van wetgevingstechniek. Dit verbaast, nu de Raad van State in een apart advies over het ontwerp van de onderhavige brief van de minister van Justitie, er juist op wees dat de hele kwestie niet een kwestie van wetgevingstechniek, maar van constitutionele aard is. ${ }^{13}$ De Raad van State gaf in zijn advies ook een uitvoerige uiteenzetting van de constitutionele aspecten van de Europese wetgevingsketen, vanaf de voorbereiding tot en met de implementatie, met analyse van de rol die nationale actoren daarbij hebben te spelen. De minister van Justitie heeft zich daar de vingers niet aan willen branden.

Het meest slagvaardig in het aldus kaltstellen van het parlement bij implementatieregelgeving op nationaal niveau is wel de minister van Economische zaken. In een voorstel van een Wet totstandkoming en implementatie EG-besluiten op het terrein van de energie, post en telecommunicatie, is het de bedoeling dat implementatie gedelegeerd wordt. In ruil daarvoor worden toezeggingen gedaan over het betrekken van het parlement bij de totstandkoming van relevante Europese richtlijnen. Zelfs de Tweede Kamer - de kamer die wetgeving als zijn minst belangrijke taak beschouwt en zich maar zelden heeft bekommerd om het verdwijnen van zijn wetgevende bevoegdheid - schrok van de verreikendheid van de voorstellen. In de nota naar aanleiding van het verslag van de kamercommissie, stelt de minister met enige omhaal van woorden dat het EG-recht nu eenmaal snelle implementatie vergt en dat het parlement daaraan in de weg staat door betrokkenheid bij implementatie-wetgeving. Vooraf mag het parlement meepraten, al heeft dat niet altijd effect, en later hoeft het dan bij de implementatie niet meer betrokken te worden, zo luidt het door de minister van economische zaken voorgestane schema. Wat betreft de Grondwet wordt voor het gemak, maar niet geheel toevallig, een omstandig beroep gedaan op een wetenschapper die een meer regeringsvriendelijke benadering van de kwestie heeft. Die wetenschapper wees er overigens wel op dat een en

waarin de richtlijn om een ingrijpende nationale keuze vraagt, danwel om aanpassing van de reikwijdte van nationale wetgeving.'

${ }^{11}$ Ibidem, p. 3.

${ }^{12}$ Overigens wijst de minister met zijn slottekst op een discussie die nog zal moeten worden gevoerd over een kabinetssstandpunt waarop nu meer dan twee en een half jaar wordt gewacht over de EU en de Grondwet, op basis van de studie van Besselink c.s. 2002.

${ }^{13}$ Zie bijlage 1 van kamerstuk 29200 VI, F, blz. 6: 'Het onderwerp dat in het ontwerpkabinetsstandpunt aan de orde is, betreft dan ook een constitutioneel vraagstuk en niet slechts een van wetgevingstechniek.' 
ander eigenlijk wel een grondwetswijziging waard is; een punt dat de minister wel vermeldt, maar waarbij deze slechts opmerkt dat dat geen kwestie van de minister van economische zaken alleen is - waarmee kennelijk de grondwettigheid en verregaande constitutionele implicaties van het wetsvoorstel in diens ogen voldoende zijn afgedaan. ${ }^{14}$

\subsubsection{Politieke controle over de uitvoerende macht}

Behalve op het punt van de regelgeving raakt de volksvertegenwoordiging ook gemarginaliseerd wanneer het gaat om politieke controle.

Hoewel er wel sinds het begin van de jaren '90 toenemende pogingen zijn om de rol van de nationale executieve bij de EU-besluitvorming te onderwerpen aan een vorm van politieke controle door het nationale parlement, moet worden vastgesteld dat deze niet de gelijke is noch kan zijn van parlementaire controle in puur nationale context.

Bepaalde omstandigheden, zoals een zwakke feitelijke controle, een ernstig gebrek aan ondersteuning van kamercommissies en kamerleden, het niet of gebrekkig informeren door de regering van het parlement en het uitspelen van bicameralisme, dragen aan die marginalisering bij.

Men kan stellen dat er ook een meer structurele, constitutionele onmogelijkheid is om de nationale executieve verantwoordelijk te houden. Het probleem schuilt daarin dat in nationale context - althans in Nederland - het parlementaire stelsel een mate van dualisme veronderstelt die in de Europese context niet kan functioneren. Dit dualisme bewerkstelligt en garandeert de eigen bevoegdheid en zelfstandige politieke rol van de executieve, waarbij het accent ligt op politieke controle achteraf.

Op Europees niveau kan het Europees Parlement de Raad of leden daarvan niet naar huis sturen. ${ }^{15}$ Maar is het dan op nationaal niveau een zinvolle sanctie om de eigen vertegenwoordiger in de Raad tot ontslag te dwingen? Anders dan ten aanzien van nationale crises, kan het gevolg daarvan nooit die van een verandering van beleidsuitkomsten zijn, het waaien van een andere politieke wind. Daarvoor is in de Raad immers de medewerking van de andere leden vereist. Een nationale parlementaire sanctie jegens het eigen lid van de Raad zal al met al weinig indruk op die anderen maken. De politieke samenstelling - als men dat al mag zeggen van de Raad - staat helemaal los van de politieke kleur van de vertegenwoordiger van deze of gene lidstaat. Met een andere Nederlandse minister zal de Raad niet van kleur verschieten, en zelfs als dat toevallig wel 'ns zo is, zal de wind niet plots uit andere politieke windrichting komen, omdat de Raad in ideologische zin nooit politiek homogeen zal zijn.

Deze constitutionale onmogelijkheid van politieke verandering verergert de meer afgeleide problemen van politieke verantwoording die we hiervoor vermeldden (gebrek aan informatie, etc.) en geeft regeringen de mogelijkheid om verantwoordelijkheid te ontlopen. De faits accomplis van de EU-besluitvorming zijn de frustratie van het constitutionele systeem van politieke verantwoordelijkheid en verantwoording.

Wel kan het nationale parlement dreigen met de ultieme sanctie, maar omdat deze een weinig constructieve bijdrage kan leveren aan toekomstige beleidsuitkomsten is deze van een andere orde dan in puur nationale context. Deze stand van zaken is in Denemarken al aan het begin van het lidmaatschap aanleiding geweest tot het een ontwikkelen van een

\footnotetext{
${ }^{14}$ Zie kamerstuk 29474, nr 6; voor wat betreft de 'ontwikkelingen in de wetenschap', p. 3-4.

${ }^{15}$ Het kan wel de Commissie heenzenden, maar zelfs dat is nog nooit gelukt, zelfs niet toen de corrupte houding van de Commissie-Santer aan het daglicht waren getreden.
} 
constructie waarbij het nationale parlement fungeert als politieke mandaatgever aan de regeringsvertegenwoordiger in de Raad, waardoor in wezen een meer monistische constructie ontstaat (waarbij de politieke controle naar een eerder tijdstip is verschoven). Monistische constructies leiden in zekere zin tot een depolitisering van de executieve, zoals we weten uit bijvoorbeeld de gemeentelijke bestuurspraktijk in Nederland. Een volledige compensatie voor de politieke kwaliteit van de Europese besluitvorming op nationaal niveau biedt een dergelijke constructie dan ook niet.

Bovendien zijn in Nederland althans in het spraakgebruik 'Deense toestanden' een spookbeeld - hoe onterecht dat overigens ook is, in de eerste plaats omdat het politieke karakter van een dergelijk constructie daarmee onbegrepen blijkt, en bovendien om in Denemarken er nu juist niet sprake is van juridisch bindende mandaten of formeel parlementaire instemmingsrecht. ${ }^{16}$

\subsection{De rechter}

Op Europees niveau is er, in de woorden van Weiler, een duaal constitutioneel stelsel in een heel andere betekenis dan we er juist aan gaven: enerzijds is er sprake van een politieke besluitvorming waarin vertegenwoordigers van de executieves van de lidstaten een dominante rol spelen en die daardoor een quasi-intergouvernementeel karakter heeft (met alle stagnaties en blokkades die daarmee gepaard gaan), anderzijds is er sprake van een door het Hof van Justitie EG afgekondigd sterk supranationalisme waarin EGbesluiten het primaat hebben op nationale politieke en rechtsvormende besluitvorming, en daardoor de motor van integratie gaande houdt. De geschiedenis leert dat de bijdrage van de Europese rechter van doorslaggevende betekenis is geweest - en nog steeds in hoge mate is - bij de aansturing van het concrete proces van Europese integratie. In een teleologische benadering van Europese integratie als een progressief voortschrijdend proces waarin de executieves van de lidstaten voortdurend worden gehouden aan de besluiten die in het licht van het doel van integratie worden uitgelegd, is het de Europese rechter die een terugval in de weg staat en daaraan ook bewust in de weg wil staan.

Een van de fundamentele technieken van het Hof van Justitie is die geweest van enerzijds empowerment van individuele (rechts-)personen (voornamelijk bedrijven, ondernemers en werknemers) als dragers van rechten, anderzijds door het verschaffen van middelen aan nationale rechters om het Europees recht te handhaven. Het leerstuk van de voorrang van rechtstreeks werkende bepalingen van Gemeenschapsrecht kende een cruciale rol toe aan nationale rechters om met zulk recht strijdige nationale regels buiten toepassing te laten. Anders dan in het nationale constitutionele recht van de meeste lidstaten het geval was, werd in de rechtspraak van het Hof van Justitie EG op die manier het buiten toepassing laten van wetgeving wegens strijd met hoger recht niet voorbehouden aan bijzondere constitutionele hoven, maar een taak en plicht van elke nationale rechter.

De meest extreme vorm nam dit aan ten aanzien het scheppen van een Europeesrechtelijk regime van staatsaansprakelijkheid van nationale overheden voor niet tijdige of onjuiste implementatie van EG-regels. ${ }^{17}$ Zonder dat voor zo'n juridisch regime enige basis in de verdragen te vinden is, achtte het Hof zich bevoegd om op basis van voornamelijk

\footnotetext{
${ }^{16}$ In werkelijkheid is in de Deense verhoudingen geen sprake is van strikte en juridisch bindende mandaatverhoudingen tussen het parlement en de regeringsvertegenwoordigers. Zoiets als het vetorecht dat het Nederlands parlement heeft in derde pijler besluitvorming is naar verluidt in Denemarken ondenkbaar.

${ }^{17}$ Francovic HvJEG 19 November 1991, Jur. 1991, p. I-5357.
} 
ongeschreven beginselen (zoals het beginsel dat men gemaakte schade dient te vergoeden) nationale rechters met de competentie uit te rusten om nalatige overheden, inclusief de nationale wetgever, schadeplichtig te oordelen. Dit ging in tegen uitdrukkelijke regels van nationaal constitutioneel recht dat met name de judiciële immuniteit van de staat als wetgever (en in Engeland de Crown) stipuleerde. ${ }^{18}$

Omdat Nederland al in puur nationale context overheidsaansprakelijkheid voor schadeveroorzakende regelgeving kende, was deze jurisprudentie niet echt revolutionair. Toch moet worden vastgesteld dat er gevallen zijn waarin de rechter geroepen kan worden om in strijd met de grenzen die de Grondwet aan zijn taken stelt de wet te toetsen aan beginselen van Gemeenschapsrecht. Het gaat hier om het verbod dat voortvloeit uit artikel 120 van de Grondwet dat naar vaste rechtspraak niet slechts een verbod omvat om wetten te toetsen aan de Grondwet, maar ook om wetten te toetsen aan ongeschreven rechtsbeginselen, zoals het evenredigheidsbeginsel. Nochtans vloeit ondubbelzinnig uit de jurisprudentie van het Hof van Justitie EG voort dat in voorkomend geval ook een formele wet door de Nederlandse rechter zal moeten worden getoetst aan ongeschreven beginselen van Gemeenschapsrecht, zoals aan het beginsel van evenredigheid en rechtszekerheid, maar ook aan grondrechten die bij gebreke van een juridisch bindende geschreven grondrechtcatalogus als beginselen van Gemeenschapsrecht gelden. ${ }^{19}$

Wat betreft de toegenomen rol van de rechter moeten we vaststellen dat naast het nationale mandaat de nationale rechter een daarvan onafhankelijk EU mandaat heeft gekregen die althans gedeeltelijk kan leiden tot verdringing of vervanging van delen van het nationale mandaat wanneer een nationale rechter geconfronteerd wordt met een regel van Europees recht (wat Nederland betreft bijvoorbeeld door verplichte toetsing van de wet aan ongeschreven beginselen van Gemeenschapsrecht) (Claes, 2004).

\subsection{Een eerste conclusie}

Overzien we het voorgaande, dan moet worden vastgesteld dat het parlementair stelsel onder druk komt te staan. We bewegen in elk geval in Europese aangelegenheden in de richting van een quasi-monarchaal (zo men wil quasi-presidentieel, zij het dat de regering ongekozen is) regeerstelsel, waarin de regering een eigen regelgevend domein claimt, en ook in politiek opzicht een rol speelt waartegen het parlement niet even effectief als in nationale context zijn machtsmiddelen kan inzetten.

De rechter op zijn beurt heeft een ongeschreven mandaat ontvangen op basis van de jurisprudentie van de Europese rechter. Deze verschaft een plena potestas om nationale overheden, inclusief de wetgever, te onderwerpen aan de supervisie van de nationale rechter zodra EG-recht aan de orde is.

\section{De voorrang van het EG-recht als dogma van Nederlands staatsrecht}

Dit alles heeft zich kunnen ontwikkelen zonder dat een fundamentele discussie over de constitutionele invloed van de Europese integratie heeft plaatsgevonden. Sterker, er is in

\footnotetext{
${ }^{18}$ Het Britse verbod van rechterlijke bevelen tegen de Kroon werd terzijde gesteld in Factortame I, zaak C213/89, Jur. 1990, p. I-2433; de Duitse immuniteit van de wetgever voor schadevergoedingsacties bij de gewone burgerlijk rechter werd in strijd met EG-recht geacht in Brasserie du Pêcheur, 5 maart 1996, gevoegde zaken nr. C-46/93 en C-48/93, Jur. 1996, I-1029.

${ }^{19}$ Het EU Handvest voor de Grondrechten is niet juridisch bindend. Het Hof van Justitie EG heeft geweigerd om in voorkomende gevallen te refereren aan het Handvest als ware het een bron van recht; een notoir geval was zaak C-50/00 P, 25 juli 2002, Unión de Pequeños Agricultores.
} 
bepaald opzicht sprake van een blinde vlek in het Nederlandse staatsrecht. Zelden is er gesproken over de consequenties van de Europese ontwikkelingen voor de nationale constitutie, en wanneer zulks gebeurde was dat niet altijd op doorwrochte wijze, zoals wel het geval was in Duitsland, Frankrijk, Italië, het Verenigd Koninkrijk en andere lidstaten.

Een verklaring hiervoor kan worden gezocht in de constitutionele positie die het internationale recht en het recht van internationale organisaties in de Grondwet hebben verworven sinds de herziening na de Tweede Wereldoorlog van de bepalingen over de internationale betrekkingen. In 1953 (met een 'technische' wijziging in 1956) kwamen de bepalingen in de Grondwet die thans te vinden zijn in artikelen 90, 93 en 94:

Artikel 90

De regering bevordert de ontwikkeling van de internationale rechtsorde.

Artikel 93

Bepalingen van verdragen en van besluiten van volkenrechtelijke organisaties, die naar haar inhoud een ieder kunnen verbinden, hebben verbindende kracht nadat zij zijn bekendgemaakt.

\section{Artikel 94}

Binnen het Koninkrijk geldende wettelijke voorschriften vinden geen toepassing, indien deze toepassing niet verenigbaar is met een ieder verbindende bepalingen van verdragen en van besluiten van volkenrechtelijke organisaties.

Deze bepalingen geven een duidelijk signaal omtrent de openheid van de constitutie voor recht van internationale oorsprong. Beoogd werd om ook de deelname aan Europese samenwerkingsorganisaties als de EGKS en later EEG mogelijk te maken, zonder dat het nationale grondwettelijke of wettelijke recht hiertegen obstakels zouden opwerpen.

Paradoxaal genoeg neemt het grootste deel van de Nederlandse staatsrechtelijke literatuur tegenwoordig aan dat het Europese recht uit eigen hoofde, en dus buiten de Grondwet om, in de nationale rechtsorde gelding verwerft. ${ }^{20}$ Van groot praktisch belang is dit overigens nauwelijks, want zowel linksom als rechtsom verwerft het Gemeenschapsrecht eenzelfde bevoorrechte positie boven strijdig nationaal recht. Maar principieel lijkt het te duiden op een houding waarin de nationale constitutie niet slechts ondergeschikt is aan besluitvorming van internationale oorsprong, maar zelfs irrelevant is.

Hoe dit zij, duidelijk is dat de Nederlandse constitutie zichzelf niet als exclusief beschouwt. Dit is een groot verschil met lidstaten als Duitsland, Frankrijk en Italië waar de nationale grondwet beschouwd wordt als bron van de nationale rechtsorde en als ultieme legitimatie van de uitoefening van politiek gezag, ook als dat van internationale of Europese oorsprong is. De idee van volkssoevereiniteit die met deze benadering nauw verbonden is, ontbreekt in de Nederlandse constitutionele context. Enerzijds vergemakkelijkt dit de aanpassing aan maatschappelijke en internationale ontwikkelingen; anderzijds leidt het tot afwezigheid van een constitutioneel debat, waardoor er sprake is van een zekere constitutionele bloedarmoede.

\footnotetext{
${ }^{20}$ Zie voor een overzicht van de juridische ins and outs hiervan, Besselink c.s. 2002, $28-42$.
} 


\section{$4 \quad$ Exogene en autonome wijzigingen}

De hierboven aangeduide constitutionele verschuivingen zijn niet alleen veroorzaakt door de EG/EU invloed die als het ware van buiten naar binnen werkt.

Ongetwijfeld zijn ook andere meer autonome ontwikkelingen in de rechtsstaat binnen de context van ontwikkeling van de post-moderne welvaartsstaat debet aan die verschuivingen.

Van de spreekwoordelijke beperkte nachtwakersstaat van de $19^{\mathrm{e}}$ eeuw - de eeuw van de Grondwet - waarin de staatsfunctie vooral lag in het handhaven van door de wetgever voornamelijk in de codificaties, ${ }^{21}$ gegeven geboden en verboden, ontwikkelde de overheidstaak zich naar het welvaartsstaatsmodel, waarin de staat allerlei taken op zich nam, die positieve overheidsprestaties ten behoeve van de burger vergden. Een nieuw accent in de wetgeving deed zich voor: regelgeving breidde zich uit en verschoof van tot de burger gerichte geboden en verboden naar het verschaffen van een basis voor overheidsoptreden. ${ }^{22}$ Dit kon slechts door ruim gebruik te maken van delegatie van zowel regelgevende als discretionaire bestuursbevoegdheid aan de uitvoerende macht. Handhaving verdween sterk naar de achtergrond ten gunste van uitvoering in strikte zin met uiteraard uiteindelijk de wal die het schip keert: het handhavingstekort dat emblematisch bleek bij een ramp als Enschedé en Volendam, was de keerzijde van de alleen maar in bestuurlijke prestaties geïnteresseerde overheid.

Ook in de parlementaire controle was er een verschuiving naar prestatie-gerichtheid. In de jaren '50 tot begin jaren '70 was het bouwen van minder woningen dan gepland telkens aanleiding tot politieke spanning. Incidenten-politiek concentreerde zich op missers in de sfeer van overheidsprestaties. Een oer-klassiek parlementair instrument als het budgetrecht raakte verwaarloosd. Pas de déconfiture van de steunverlening voor de scheepsbouw en de daaraan gewijde RSV-enquête in de jaren '80 luidde (onder meer) een terugkeer in naar aandacht voor de controlerende functie van het budgetrecht.

De om zich heen grijpende overheidsactiviteit, met een exponentiële groei van het bestuursrecht, vond een tegenwicht in de groei van de rechtsbescherming. Deze vond vooral plaats door de uitbreiding van de rechtsmacht van de bestuursrechter; maar ook de burgerlijke rechter ging steeds verder in het verschaffen van bescherming aan justitiabelen tegen de overheid (sterker: als men bij de burgerlijke rechter terecht kan, dan blijkt deze aanzienlijk ruimere bescherming te bieden dan de bestuursrechter doorgaans doet).

Dit alles waren ontwikkelingen die los stonden van de Europese integratie - men vindt ze ook in andere Europese landen die geen deel uitmaken of uitmaakten van de EU. Toch moet gezegd worden dat de Europese ontwikkeling zeker zijn bijdrage leverde. De bewegingen grepen in eenzelfde richting op elkaar in. Waar de constitutie niet resistent was of kon zijn tegen de ontwikkelingen in de rechtsstaat, zo was zij evenmin - of misschien des te minder - resistent voor de ontwikkelingen die de Europese integratie bracht.

\footnotetext{
${ }^{21}$ Zie het uit 1815 stammende artikel 107 Grondwet: ' 1 . De wet regelt het burgerlijk recht, het strafrecht en het burgerlijk en strafprocesrecht in algemene wetboeken, behoudens de bevoegdheid tot regeling van bepaalde onderwerpen in afzonderlijke wetten.'

${ }^{22}$ Het is niet geheel toevallig dat in 1983 de in de vorige voetnoot genoemde codificatie-bepaling werd uitgebreid met het volgende tweede lid: ' 2 . De wet stelt algemene regels van bestuursrecht vast.'
} 
Men kan dit illustreren aan de hand van de wijze waarop het parlement met het begrotingsrecht omgaat. De financiële grenzen die voortvloeiden uit de vereisten voor deelname aan de ene Europese munt vielen samen met de financiële kenteringen voor de presterende overheid. Het een en ander bracht mee dat het parlementair begrotingsrecht, met een begin in de jaren '80 (de 'bezuinigingsoperaties' ten tijde van het kabinet Van Agt) in de loop van de jaren '90 verwerd tot een instrument van financiële beheersing, waarbij de grenzen van de verzorgingsstaat en de EMU-criteria (thans het Stabiliteitspact) elkaar versterkende motieven waren. Symptomatisch voor het parlementair begrotingsrecht is de conventie die in de Tweede Kamer is ontstaan dat leden niet langer het recht meer hebben om begrotingsamendementen voor te stellen die geld kosten, tenzij zij aangeven hoe de financiering gecompenseerd kan worden. Dat dit het budgetrecht wezenlijk kan ondermijnen moge duidelijk zijn, zo goed als evident is dat het parlementair budgetrecht natuurlijk fundamenteel gemarginaliseerd is geraakt door de eisen die de EG in het kader van het Euro-beleid stelt.

Opgemerkt moet worden dat de 'autonome' verschuivingen in de constitutionele verhoudingen in een andere context plaatsvinden dan de verschuivingen ten gevolge van de Europese integratie. Dit maakt de Europese invloed, niet alleen in de ogen van Eurosceptici, maar ook in werkelijkheid meer insidious dan de autonome ontwikkelingen die eenzelfde richting op gaan. Aan de ontwikkelingen van de Europese Unie kan men zich moeilijker onttrekken, en bovendien zijn ze moeilijker unilateraal in te kaderen of om te buigen. Het Europese recht claimt een suprematie die soms noch qua vorm noch qua inhoud ruimte laat om aan de gevolgen daarvan wel of niet tegemoet te komen. Als bijvoorbeeld het Europees constitutionele recht voorschrijft dat alle nationale regelgeving, inclusief de formele wetten, moet voldoen aan ongeschreven rechtsbeginselen als het proportionaliteitsbeginsel en dat de rechter de toetsing aan zulke rechtsbeginselen heeft te voltrekken, dan kan geen regel van nationaal constitutioneel recht dat op enige manier nader accomoderen of modificeren in het licht van nationale eisen van democratie. Men zou kunnen zeggen dat de nationale rechtsordes van de lidstaten als het ware tot de rol van ondergeschikte uitvoerders van Europees recht zijn teruggedrongen telkens wanneer Europese besluiten een rol spelen. Ook al is een meer pluralistische benadering heel veel aantrekkelijker en wenselijker, dit in wezen hiërarchische perspectief op de verhouding tussen de nationale en Europese politieke en constitutionele ordes is in toch vrij veel gevallen juridisch bezien onontkoombaar.

\section{$5 \quad$ Conclusie: De Europese toekomst van de Grondwet}

In de Grondwet als formele constitutie ontbreekt elke weerspiegeling van geconstateerde verschuivingen in de materiële constitutie, voor zover die (mede) voortvloeien uit ontwikkelingen in de EU. Hiervoor zijn diverse redenen aan te voeren.

Ten eerste kan dit verklaard worden uit de constitutionele openheid voor de internationale rechtsorde, de Europese rechtsorde incluis. Hier is de 'openheid' van de constitutie van doorslaggevende betekenis.

Een ander deel van de verklaring kan zijn dat sommige van de beschreven verschuivingen zich voordoen in bepaalde verhoudingen binnen het institutioneel complex die zelf niet in de Grondwet zijn vastgelegd (maar daar wel door worden verondersteld), zoals het geval is met de verhouding tussen regering en parlement en tussen regering en rechter. Hier is het 'materiële' karakter van de constitutie 
doorslaggevend, zonder dat dit formalisering vergt. Pas wanneer een dergelijke materiële praktijk zich daadwerkelijk tot normatieve werkelijkheid heeft vastgezet, kan het tijd worden dit ook formeel vast te leggen. Kennelijk is in de ogen der politici daarvoor het moment nog niet aangebroken.

Een derde verklaring kan zijn dat sommige van de beschreven fenomenen zich in de verhouding tot de EU voordoen, maar niet of minder in puur nationale context - zoals de rol van het parlement tegenover de regering, die immers in puur nationale context soms toch op de traditionele constitutionele wijze functioneert, althans kan functioneren.

Ten slotte is onzekerheid over de toekomst van de Europese Unie zelf een reden voor terughoudendheid in formele aanpassingen van de Grondwet. De Unie is weliswaar van gestaag toenemende betekenis geworden, maar de precieze constitutionele verhoudingen in de EU zelf zijn nog niet in definitieve bedding geraakt. De dubbelzinnigheid van het constitutionele arrangement dat in het Constitutionele Verdrag is vastgelegd getuigt daarvan. Of dit Constitutionele Verdrag binnen afzienbare tijd, zo ooit, in werking zal treden, is nogal onzeker.

Daarbij komt dat de recente zeer grote uitbreiding van het aantal lidstaten een reden te meer is voor enige afwachtendheid omtrent de toekomstige ontwikkeling van de EU.

Dit afwachten is niet zozeer onwil, onvermogen of desinteresse, maar een benadering die past bij een nationale constitutie die eerder wil codificeren dan modificeren. 
Besselink, L.F.M., H.R.B.M. Kummeling, R. de Lange, P. Mendelts en S. Prechal De Nederlandse Grondwet en de Europese Unie. Europa Law Publishing, Groningen 2002.

Claes, Monica, The national courts' mandate in the European Constitution, diss. UM, 2004; handelseditie in voorbereiding in de serie Modern Studies in European Law, Hart Publishing, Oxford.

Versnelde implementatie van EG- en andere internationale besluiten, Advies van de Interdepartementale Commissie Europees Recht, februari 1999 